\title{
The Optimum Wood Procurement Scenario and Its Dynamic Management for Integrated Energy and Material Production in Carbon-Neutral Forest Industry
}

\author{
Teijo Palander * ${ }^{(B)}$ and Jari Takkinen \\ Faculty of Science and Forestry, University of Eastern Finland, P.O. Box 111, FI-80101 Joensuu, Finland; \\ jari.takkinen@harvestia.fi \\ * Correspondence: teijo.s.palander@uef.fi
}

check for updates

Citation: Palander, T.; Takkinen, J. The Optimum Wood Procurement Scenario and Its Dynamic Management for Integrated Energy and Material Production in Carbon-Neutral Forest Industry. Energies 2021, 14, 4404. https:// doi.org/10.3390/en14154404

Academic Editors: Patrik Thollander, Thomas Zobel and Alberto-Jesus Perea-Moreno

Received: 25 May 2021

Accepted: 19 July 2021

Published: 21 July 2021

Publisher's Note: MDPI stays neutral with regard to jurisdictional claims in published maps and institutional affiliations.

Copyright: (C) 2021 by the authors. Licensee MDPI, Basel, Switzerland. This article is an open access article distributed under the terms and conditions of the Creative Commons Attribution (CC BY) license (https:/ / creativecommons.org/licenses/by/ $4.0 /)$.

\begin{abstract}
The digitalization of the forest sector, the increased demand of energy-wood, as well as faster market changes have increased the number of challenges for wood procurement of the forest industry. The aim of the study is to optimize wood procurement (upstream of supply chain) of energy and material production in integrated situations, and to consider the effects of production changes on the management of procurement regions. Three scenarios described integrated production situations in a carbon-neutral forest industry: (1) declining export, (2) energy reform, and (3) extensive energy reform. Time-varying capital-, cost-, and energy efficiency of the dynamic wood-flow model affected the competitiveness of the procurement regions. As a novel contribution, energy efficiency was modeled using the price of emission allowance as a cost parameter. The results show the positive effects of the energy reforms, which partly compensate for the declining exports. In addition, it is possible to change wood procurement in the regions in a market-oriented way. Decision makers should optimize purchases, inventories, and procurement resources as business processes, which are also considered success factors for the forest industry in integrated production situations. The strategic solution of extensive energy reform provides a potential approach for carbon-neutral customer-oriented supply chains, but it needs tactical energy efficiency analysis in future studies of sustainability, if the ultimate goal is to implement a carbon-free forest industry and bioeconomy.
\end{abstract}

Keywords: carbon neutrality; dynamic linear optimization; energy efficiency; process management; renewable wood; sustainability

\section{Introduction \\ 1.1. Background}

The forest industry is, globally, experiencing the greatest transformation in its history, which is also the fastest ever. Pulp and plywood machines and even entire paper mills have closed [1]. In addition, sawmills have closed and the production volume of some has fallen during the last few years. We are also experiencing digital changes in livelihood towards a new era of bioeconomy and a low-carbon economy [2], which affect the entire forest sector. In this context, the bioeconomy comprises all production that produces, uses, processes, and markets renewable resources $[3,4]$, as well as the consumption of products that are made from renewable resources $[5,6]$.

The Finnish forest sector will continue to change significantly over this decade $[7,8]$. Forestry, and the use of wood products and energy obtained from forests, will diversify, which also creates challenges for the technological development sector. The forest industry is becoming increasingly integrated into a sustainable bioeconomy with the support of new investments in the chemical and energy industries. In practice, current and new energy efficiency investments in the forest industry will increase the demand and supply for renewable wood $[9,10]$, but will also promote a transition of society, from the use of fossil raw materials to national and social well-being by using carbon-neutral and more 
sustainable industries [11,12]. Furthermore, increased harvesting of Finnish forests also contributes to increasing the carbon sink of forests [13-15].

\subsection{Management of Wood-Procurement Process}

In Finland, wood procurement is concentrated on industrial corporations' own woodprocurement organizations [16]. There are also smaller-scale wood-procurement companies that serve several customers in the forest and energy industries. The entry of new participants into the market can be understood as a positive effect from the point of view of several buyers of wood raw materials, as well as of wood sellers. It seems that the business of wood-procurement organizations is moving towards both mill customers and forest owners. Naturally, wood procurement has always been significant for the success of the forest industry and now, increasingly, for the energy industry because raw materials synergistically combine the mechanical, chemical and energy industries. From the point of view of an integrated industry, the most important development targets for wood procurement logistics are raw material quality, wood price, other procurement costs, security of supply, and the responsiveness of wood suppliers. To maintain successful operating conditions, a wood procurement business must be profitable, but must also be a socially acceptable, as well as be able to provide customers with environmentally (e.g., carbon neutrality) and ecologically (e.g., diversity) sustainable approaches [17].

In this study, the focus is on activities of business processes in a wood procurement organization. A process can be defined as a strategy of logically related activities, as well as the resources needed to implement them to achieve results from activities. Furthermore, a process is an entity formed by related activities that starts with a customer's needs and ends back at a customer's needs. Strategic processes can be viewed hierarchically as three levels: the core process, the sub-process, and the supporting process [18]. As the whole, the concept of "process" consists of activities, resources, and outputs associated with performance. On the other hand, processes can also be used as the ability of an organization to understand its own operations and effectiveness. The starting point in process management is something permanent and recurring that can be agreed upon, as well as able to be modeled and developed.

Based on the needs of a customer in terms of using wood (production plant), we started to think about what products and services (wood assortments) can best satisfy their needs (wood demand). On the other hand, processes mean a logical chain of operations that starts with a wood seller's willingness to sell and returns to the wood seller as a new potential service. A good service can, therefore, be considered be based on a customer-tocustomer process, which are based on an organization's overall goals in the context of a strategic model. The idea of the strategic model is to avoid partial optimization and to favor total optimization. Identifying and modeling processes enable the ability to succeed in competition with wood-procurement companies, which can be seen through transforming a company's core competencies through core processes into a strategic capability that generates significant added value for customers.

Strategic optimization of wood procurement is a key factor for profitable, energyefficient and sustainable operations $[19,20]$. Based on the supply of wood from private forests and the demand volumes of mills, a strategic procurement plan is formed. The targets of wood purchase are forest stands, where logistics aim to find the most suitable delivery address for all types of wood assortments. It must also generally be the priority to have a cost-efficient destination for one's own production facilities. In this respect, the role of a wood-procurement organization is to manage the optimization of several parallel and intersecting wood supply chains in an ever-changing production situation, as well as to take care of uninterrupted wood flow through imports, purchasing, and inventories [21]. This complex optimization problem can be formulated as a wood flow model (Figure 1). 


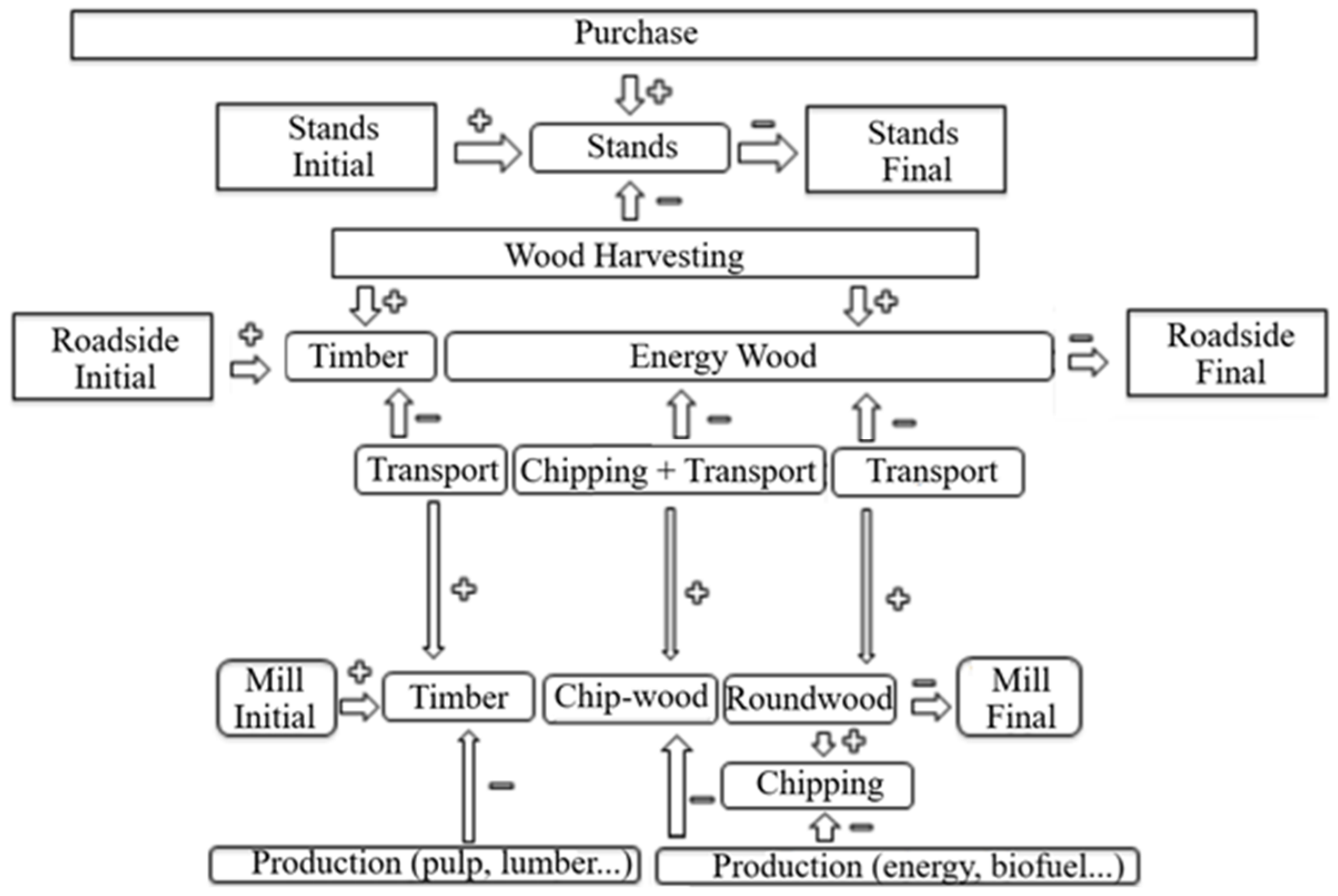

Figure 1. Wood flow model of wood procurement in an integrated material and energy industry.

A wood flow model can be described based on the process ideology. Accordingly, wood procurement has two core processes: it starts from the wood purchase from forest owners and ends at wood procurement for mill customers. Further, wood flow is descried as four sub-processes: inventorying, purchase, harvesting, and transport (including roadside chipping). In addition to these elements of the model, wood procurement needs supporting processes, such as administration, IT support, and training. Currently, wood harvesting, transportation, and chipping are outsourced sub-processes, which are considered as justified because the internal business costs of the procurement company are higher than the internal costs of the operating company [22]. These sub-processes consist of separate functions, e.g., preparation of harvesting schedules, quality and quantity monitoring, control, purchase planning, etc.

The starting point for describing core processes is the identification of functions of the wood-procurement company and its customers, and other relevant stakeholders. Wood procurement for customers is the core process that serves sawmills, plywood mills, pulp mills, paper mills, and energy plants. The products of the process are logs and fiber grades, as well as energy fractions, which are called wood assortments. As another core process, the purchase of wood from forest owners, or their organizations, is applied to services for customers who sell wood to companies as a partner. The aim is to provide a comprehensive service for forest planning on a turnkey basis, with quality and cost being competitive so that forest owners avoid losing time during forest work.

When looking at wood procurement as a business organization, the primary criterion from the perspective of process management theory is an organization's ability to generate added value from the product or service to the mill customer who ultimately pays for it. Process thinking makes it clear that the Euros received from the production of wood assortment come only from the customers who need them. In an analysis of the wood supply chain (upstream), just like of any other parts of a supply chain (midstream and 
downstream), it is essential to remember that only members of the supply chain share revenue from the consumer of the downstream chain. If it is not possible to increase the revenue from processed products by increasing prices and sales volumes, the only remaining way to increase the revenue generated by members of the supply chain is to reduce the costs in the chain. While, from a service level perspective, linear optimization that minimizes total costs is done at the expense of a reduction in service level, the total costs of wood procurement must be minimized with the help of mathematical models and a functioning decision support system based on operational research. Through the logic of the process-based model, anything that is not important in the supply chain in terms of the requirements of wood assortments purchased by genuine paying customers should be eliminated as unnecessary cost drivers [17]. The simpler the wood flow and "the less hands it passes through" for the desired performance, the cheaper the total costs will be. Complex operating methods and systems increase the possibility of errors and lead times in the wood flow.

Since the 1990s, decision support systems have been used in wood procurement in the forest industry, which originated from operational research. Although model size is not a programming problem anymore, the complexity of integrated materials and energy production systems makes existing engineering, simulation, and statistical tools insufficient to provide efficient strategic solutions $[15,18,23]$. In addition, future fluctuations in energy prices and emission allowance prices, as well as strategic investment decisions by the midstream part of the chain will affect the upstream part of the supply chain and complicate the issue $[1,24]$. Therefore, decision support tools may be a means to offer necessary support to wood-procurement management. It has been justified by previous studies that linear programming provides a methodology for determining optimal strategies in order to minimize the total costs in the supply chains of the forest industry $[17,23,25]$. Such a methodology is used in pulp and paper mills. For example, the MIND method is applied, which was developed for the optimization of dynamic industrial energy systems [23], which comprise the midstream of the supply chain. It has even been tested for use in an optimization model to evaluate industrial symbiosis in the forest industry [26]. The need to develop such optimization methods in the upstream parts of the supply chain, including wood-procurement companies, is an important decision support for showing the effects of energy reforms and/or reducing $\mathrm{CO}_{2}$ emissions. In addition, most medium-sized companies only have limited possibilities to apply such models and methods.

\subsection{Strategic Planning of Wood Procurement on a Scenario Basis}

The strategy became a concept in the business world in the 1950s. The military view of strategy emphasizes a hierarchical level, in which case the strategy is understood as a function for which top planning bears responsibility. The strategy can be considered as a solution by which existing resources are optimized to achieve goals [17]. According to this definition, the strategy of wood-procurement management is, therefore, an action plan, while its implementation and adjustment are tactical activities; however, the characteristics typical of a business strategy differ from above-described military theories. It does not cause immediate action, and merely creates a direction. The strategy is always based on a lack of information about decision options and consequences. Strategies aim at competitive advantages, efficiency, and flexibility. Indeed, strategy is most often seen as a path between a company's mission and vision. Thus, a business strategy is ideologically the path along which the goals of a core business process are achieved.

Scenario-based strategic planning is a means of leading organizations in times of uncertain transition. It shows new alternatives for management and guides organizations to identify possibilities that might otherwise have gone unnoticed. In this way, sustainable solutions can be identified from less sustainable ones. Scenario thinking is a perspective, where the future is seen as a possibility of several different alternative states. The scenario can create a logically progressive series of events, the purpose of which is to show how a possible future state develops, step by step, from the current state. It can be used to assess 
the efficiency of strategies under changed circumstances, which logically leads to either redefining the strategy or specifying it in the organization. The future scenario is firmly based on currently available information about a future state that includes, not only an analysis of the current state, but also descriptions of possible processes that gradually lead from the present to the future. The purpose of the scenario is to serve as a tool in future management planning, which uses optimization models.

In the forest industry, cyclical market fluctuations have always been strong, and price and cost developments have determined profitability. These factors, together with the ongoing structural change related to energy reforms, constitute challenges in strategic management. Over the decades, wood procurement has been executed using several strategic models with varying degrees of success. The problem has generally been a lack of customer orientation. Therefore, in this study, the factors underlying the design of wood procurement scenarios are the supply of wood from forests to mills, the production of the material industry, the production of the energy industry and the demand for end products. Thus, the supply of wood and the structure of material and energy production are interrelated [27]. Once wood procurement is understood as a process that extends to industrial end users, scenario design can begin with changes affecting wood procurement functions that may also affect the long-term strategic choices of the industry. They may be changes in the operating environment, the profitability of forest industry, the threat of Russian timber tariffs, wood-harvesting costs, transportation costs, and the reorganizing of wood procurement or growth in terms of domestic raw wood demand and bioenergy demand.

The increased use of forest energy and fuels has changed the goals of wood procurement in the relatively short term and, thus, has enabled numerous future scenarios. One important forecast that affects carbon neutrality of wood procurement is the increase in the price of European emission allowances, where the price of emission allowances is assumed to increase to EUR $60 / \mathrm{t} \mathrm{CO}_{2}$ [28]. The price has currently surged to a record EUR $44.06 / \mathrm{t} \mathrm{CO}_{2}$, which is as high as greater than $30 \%$ in 2021 [29]. The price increases wood procurement costs if fossil fuel is used in forest machines and trucks or if the uses of wood resources are not sustainable. On the other hand, increased prices for emission rights and competing fossil fuels have a significant impact on the ability of energy companies to pay for energy wood and, on the other hand, on the availability of raw materials, e.g., for the pulp industry. This scenario work could answer the questions of how much an increase in wood prices would change the availability of forest fuel for energy plants, and whether emissions trading will be able to meet national renewable energy targets for forest fuels. Numerous another trends, together with other market changes, can be described as scenarios affecting wood procurement. Scenario analyses could compare the effectiveness of different strategies, and ultimately influence the strategic management of wood procurement during sequential events.

\subsection{Aims of the Study}

The digital changes in material and energy supply, the increased demand of forest energy, and faster production changes have increased number of challenges for woodprocurement management. Therefore, scenario analyses and the new dynamic optimization model are presented for management support. The study describes steps toward a future situation using three different scenarios: declining export, energy reform, and extensive energy reform. The scenarios have been formed based partly on previous studies and forecasts $[21,30,31]$, which considered the effects of global climate warming mitigation on the national forest industry. Therefore, the time-varying parameters of the model are also designed for the price of European emission allowances and are added to the optimization model of wood procurement, which is a novel contribution to operational research for the strategic management of the industry. Although forecasts regarding carbon neutrality favor bioeconomy and energy reforms, as the research hypothesis of this study, the biggest changes in wood procurement will result from declining exports. The changes in wood procurement were analyzed in integrated production situations using dynamic linear 
programming and considering, therefore, the effects of changes on practical supply chains from the perspective of time-varying capital-, cost-, and energy efficiencies. The results obtained can be used primarily to support wood-procurement management, especially in the optimal allocation of purchasing, wood harvesting, and transportation resources in procurement regions and municipalities.

\section{Materials and Methods}

Research materials from 48 municipalities were collected from the information system of an energy and material industry corporation (Figure 2). The municipalities form six wood-procurement regions. The material for the optimization was municipal-specific historical procurement data for purchasing, wood harvesting, transportation, chipping, and inventorying, as well as their actual costs. To calculate the distance table of transportation and municipal transport costs, Google's map service was used to determine the distances between the municipalities and the locations of mills. The timber assortments used in the study were pine logs, spruce logs, birch logs, pine pulpwood, spruce pulpwood, aspen pulpwood, birch pulpwood, rotted wood, chip-wood, felling residue, pruned trunk, and stumps. There were total of 21 mills in use, of which 5 mills were using pulpwood, 10 mills were using logs and 6 were using energy wood. The logistics chains of wood assortments were determined according to the options in Figures 1 and 2, excluding the possibility of terminal storage.

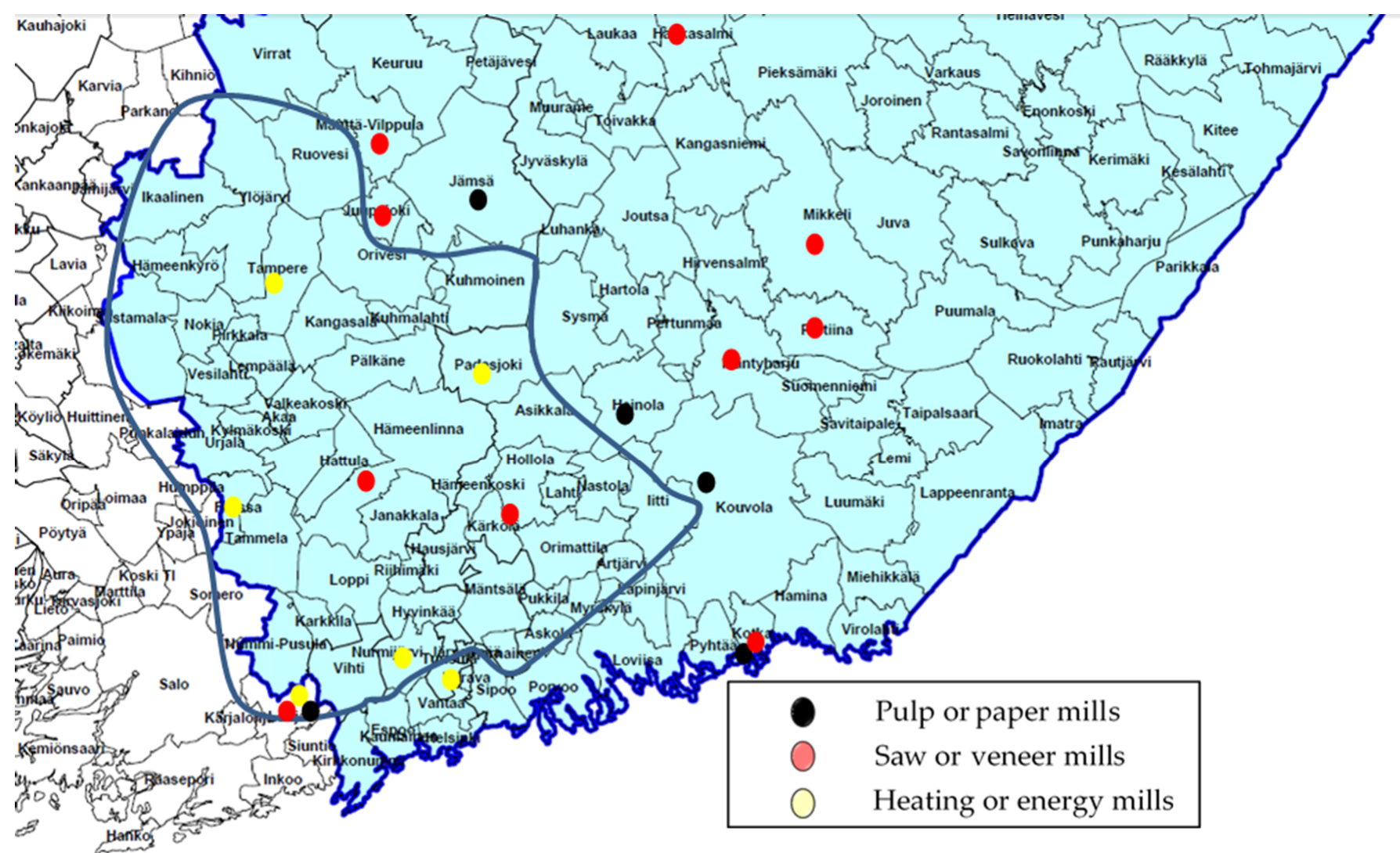

Figure 2. Wood-procurement area (inside blue line) and mills of the material and energy industry.

For optimization, the most accurate distance data possible were generated from the most important road intersections of the municipalities, based on which the transport distances to the locations of the mills were determined by the municipalities. The transportation cost was based on the industry corporation's cost calculation model. The chipping cost was determined in accordance with the corporation's contract criteria. The interest costs of the resources and inventories were $4 \%$ annually. Purchasing and procurement used 
wood assortment-specific pricing. Wood-harvesting costs were determined in accordance with the corporation's cost data.

Wood-procurement regions by municipality:

(A) Hausjarvi, Hyvinkaa, Janakkala, Lohja, Loppi, Nummi-Pusula, Nurmijarvi, Riihimaki, Vihti, Karkkila, and Tuusula;

(B) Forssa, Hattula, Hameenlinna, Lammi, Renko, Tammela, and Hameenkoski;

(C) Kangasala, Lempaala, Orivesi, Palkane, Tampere, Pirkkala, Hameenkyro, Sastamala, Ikaalinen, Mouhijarvi, Ylojarvi, Vammala, Ruovesi, and Valkeakoski;

(D) Kuhmalahti, Kuhmoinen, and Padasjoki;

(E) Asikkala, Hollola, Iitti, Jaala, Lahti, and Nastola;

(F) Artjarvi, Askola, Karkola, Myrskyla, Mantsala, Orimattila, and Pornainen.

This optimization was done using a program called PH-Opti, which is based on code that was written in house using $C$ programming language. The program uses the Lindo API sub-program, which solves the linear optimization models required by the program. The used Simplex optimization method is well described by Taha [32], which was applied here in the program to solve wood-procurement logistics. Four dynamic linear programming models were formulated for the optimization the integrated material-wood and energywood procurement by the corporation (Figure 1). In the optimization, the amount of raw material is expressed in solid cubic meters $\left(\mathrm{m}^{3}\right)$ and the results are presented as the relative numbers and the percentage changes.

The program optimizes purchase, harvesting, transportation, chipping, and inventorying of the wood procurement process. The system produces a cost-efficient solution, which is also the capital-efficient solution, because the aim is to keep the amount of capital committed to operations at the lowest possible level [30]. The amount of capital committed to wood procurement increases if the interest cost increases, e.g., from $4 \%$ to $5 \%$, or if long raw material storage times are used for inventories. In addition to the cost- and capital efficiency solution, optimization produces energy-efficient solutions because the emission costs committed to use of fossil fuels increases the operational costs. Various operating restrictions are also attached to the optimization problem, e.g., wood volumes for months of purchase and wood harvesting, the procurement range for each municipality, and the amount of raw material demanded by the mill. Wood purchases are divided into material and energy wood assortments. Constraints make the results as realistic as possible and improve the reliability of the study compared to actual practice [30]. The entire wood supply chain is examined, from purchase to mill production, which can include several sequential supply-chain parts. This kind of connected chain is also called wood flow. Modeling wood flows of the optimization problem is a key part of this research (Model 1). The model's purpose is to describe the dynamic stages of wood flows for all supply chains (Figure 1). In accordance with wood reserve targets and constraints, the purchase increases the stand reserve, which is adjusted dynamically based on roadside and mill inventory targets and constraints.

Minimization of the total costs (Min Z) was performed using an objective function that is intended for considering the costs of supply chains and finding the best procurement alternative for the lowest total cost value. The objective function takes into accounts all influencing cost factors in the supply chain, e.g., purchasing prices, emission allowance prices, contracting costs, requirements, and the interest rates of inventory time. Effects of the emission allowance price ( $35 €)$ is added as environmental costs to the procurement costs, based on environmental efficiency calculations of fuel consumption of forest machines. This programming procedure provides managers with the planning system that produces an energy-efficient solution. 


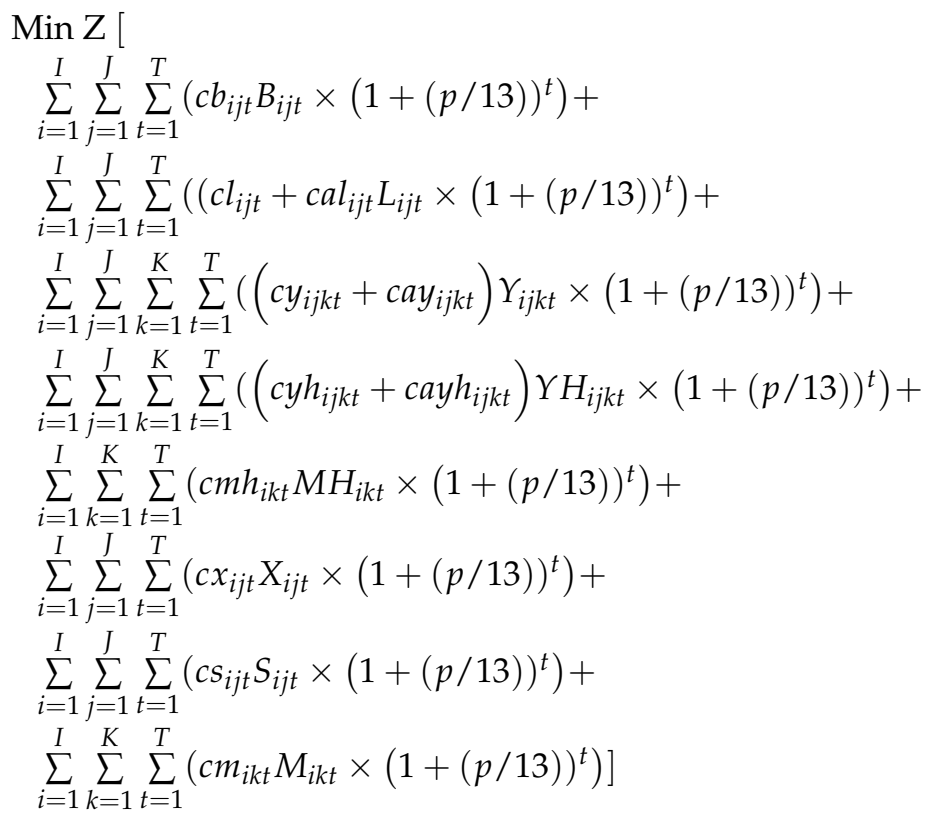

In the optimization model, the limitations and conditions must be present for the objective function of the study. These static values affect the results of what the model can achieve. The most important of these values are the amount of raw material needed by a mill, and the purchase volume of a municipality which is based on the actual purchase volumes of the industry, which describes a municipality's wood supply. In addition to static elements, operations are limited by dynamic time-varying constraints that make the model more realistic. Due to the formulation of the dynamics of wood supply, time-varying capital-, cost-, and energy efficiency affected the competitiveness of the procurement regions. The model optimizes wood-procurement operations within given conditions and constraints for a 12-month planning window. The objective function is subjected to the following restrictions:

Wood supply and demand:

$$
M_{i k t-1}+Y_{i j k t}+Y H_{i j k t} \geq D_{i k t}
$$

where $D_{i k t}$ is the wood volume of wood assortment $i$ required by mill $k$ during period $t$.

The dynamic equation of roadside inventory is:

$$
X_{i j t-1}+L_{i j t}-Y_{i j k t}-Y H_{i j k t}=X_{i j t}
$$

The volume of wood assortment $i$ stored on the roadside of municipality $j$ at the end of period $t$ equals the inventory of previous period added to harvesting and subtracted from transportation to mills.

The dynamic equation of stand inventory is:

$$
S_{i j t-1}+B_{i j t}-L_{i j t}=S_{i j t}
$$

Volume of wood assortment $i$ stored in stand's renewable wood inventory of municipality $j$ at the end of period $t$ equals to the inventory in the previous period, added to the purchase from forest owners to stand buffers and subtracting wood harvesting.

The dynamic equation of mill inventory is:

$$
M_{i k t-1}+Y_{i j k t}+Y H_{i j k t}-D_{i k t}=M_{i k t}
$$


Volume of wood assortment $i$ in mill's $k$ wood inventory during period $t$ equals to mill's wood inventory in the previous period, added to transportation from municipality $j$ and subtracted from mill consumption.

Roadside inventories:

$$
\begin{gathered}
X_{i j t=0}=X I_{i j} \\
X_{i j t=12}=X B_{i j}
\end{gathered}
$$

Roadside's wood inventory volume of wood assortment $i$ in municipality $j$ at the beginning of the planning window and at the end of the planning window, respectively.

Stand inventories:

$$
\begin{aligned}
S_{i j t=0} & =S I_{i j} \\
S_{i j t=12} & =S B_{i j}
\end{aligned}
$$

Stands' wood inventory volume of wood assortment $i$ in municipality $j$ at the beginning of the planning window and at the end of the planning window, respectively.

Mill inventories:

$$
\begin{gathered}
M_{i k t} \geq \operatorname{Mmin}_{i k t} \\
M_{i k t} \leq M \max _{i k t} \\
M_{i k t=0}=M I_{i k} \\
M_{i k t=12}=M B_{i k}
\end{gathered}
$$

Mills' wood inventory volume of wood assortment $i$ in mill $k$ at the beginning of the planning window and at the end of the planning window, respectively.

The future scenarios used in the study were formed based on existing research results and targets and assessments set at the EU level [27,28,31]. The future state develops step by step from the current state. The results of the optimization of the scenarios were compared to the baseline scenario, the wood-procurement volumes of which are based on the average procurement volumes of the forest industry corporation in 2016 and 2017. In addition to the baseline scenario, three scenarios were formed:

(1) "Declining export" scenario

Domestic production in the pulp and paper industry is expected to decrease by $30 \%$, and production in the mechanical forest industry by $15 \%$. Procurement targets are at the level from 2017 for combined energy wood and chip-wood procurement.

(2) “Energy reform" scenario

The total use of forest energy in Finland will increase to the target level stated by the government, achieving 13.5 million $\mathrm{m}^{3}$, which is expected to double energy wood procurement. No significant changes are expected in production in the mechanical and chemical wood industries.

(3) "Extensive energy reform" scenario

The total use of forest energy in Finland will increase to the target level stated by the government, achieving 13.5 million $\mathrm{m}^{3}$. In addition, biorefinery operations are expected to strengthen. Therefore, procurement targets are assumed to increase by $130 \%$ for energy wood. The additional need for biorefineries is described in the model as increased wood demands of energy plants. No significant changes are expected in the production of the mechanical and chemical wood industries.

\section{Results}

Three scenarios described the changes in integrated energy- and wood production. The scenarios affected the delivery volumes of wood assortments in the context of wood procurement (Figure 3). 


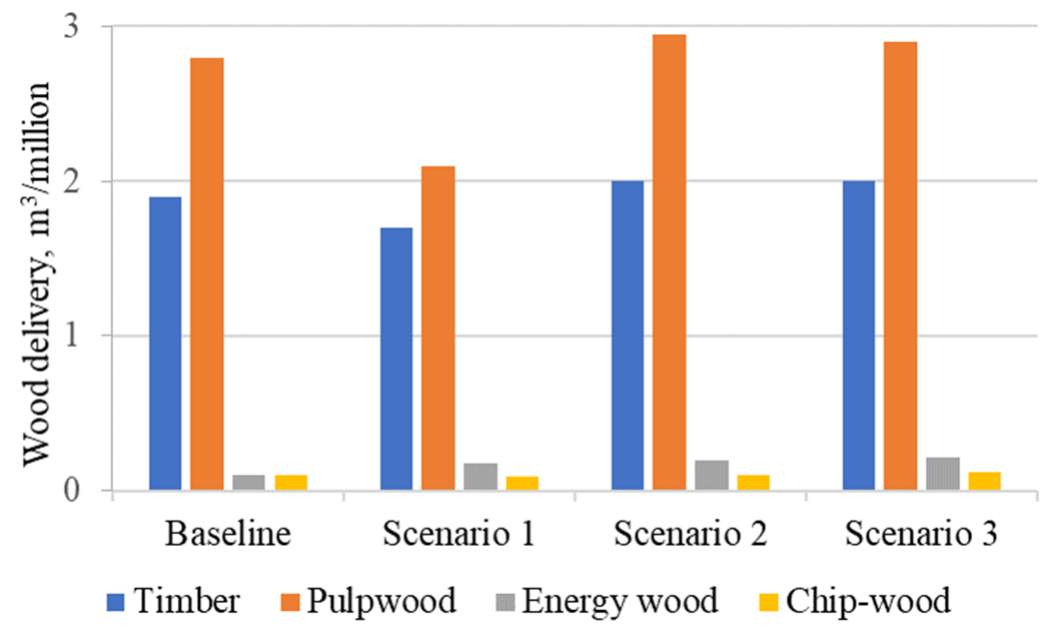

Figure 3. Comparison of wood delivery relations by wood assortments in the scenarios.

\subsection{Scenario for Declining Export}

In scenario one (declining export), total delivery volumes decreased by $19.82 \%$ compared to the baseline scenario (Table 1). The total wood-procurement costs decreased by $7.28 \%$. In the change of wood assortments, the largest increase in the delivery volume was $105.85 \%$ for energy wood and the largest decrease was $27.47 \%$ for pulpwood. The volume of chip-wood from roadside chipping delivery decreased by $7.60 \%$. This was replaced by an increase in energy wood procurement. In the change by procurement region, the largest increase in delivery occurred in wood-procurement region $\mathrm{F}(1.81 \%)$ and the greatest decrease was in wood-procurement region C (38.77\%).

Table 1. Changes in wood deliveries and total costs of wood procurement regions $(\mathrm{A}-\mathrm{F})$ in scenario one, "declining export".

\begin{tabular}{cccc}
\hline Delivery & Baseline Scenario & Scenario One & Change-\% \\
\hline Log wood & 0.39 & 0.33 & -14.91 \\
Pulpwood & 0.58 & 0.42 & -27.47 \\
Energy wood & 0.02 & 0.04 & 105.85 \\
Chip wood & 0.01 & 0.01 & -7.06 \\
A & 0.13 & 0.13 & -6.18 \\
B & 0.14 & 0.09 & -33.70 \\
C & 0.33 & 0.20 & -38.77 \\
D & 0.16 & 0.16 & 1.17 \\
E & 0.11 & 0.10 & -16.29 \\
F & 0.12 & 0.13 & 1.81 \\
Delivery volume & 1.0 & 0.80 & -19.82 \\
Procurement costs & 1.0 & 0.93 & -7.28 \\
\hline
\end{tabular}

Total wood delivery volumes were largest in January, because optimization decreased inventories of wood flow, i.e., faster lead times and the best capital efficiency were reached in the adjustment process (Figure 4). Accordingly, roadside chipping applications were only made during the period from January to May, and the highest roadside chipping volumes were in January. Dynamics of wood deliveries produced the steady state of wood procurement at end of the year. During the months of September, October, November, and December the supply chains were also cost- and energy efficient, because the total costs were minimized, and the prices of the emission allowance were used in the model. 


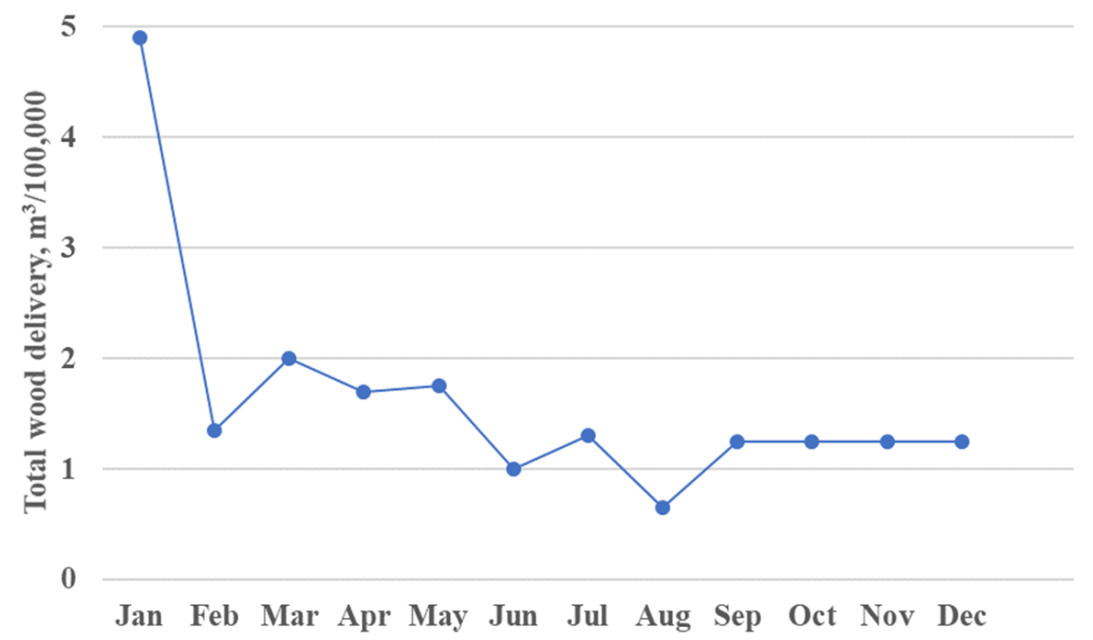

Figure 4. Dynamics of wood deliveries and steady state of wood procurement at end of 2017.

\subsection{Scenario for Energy Reform}

In scenario two (energy reform), total wood delivery volumes increased by $4.05 \%$ compared to the baseline scenario. The total wood-procurement costs increased by $15.95 \%$ (Table 2). In the change by wood assortments, the largest increase in the delivery volume was $118.84 \%$ for energy wood. The delivery volume of pulpwood changed the least, by $1.22 \%$. The volume of roadside chipping applications and chip-wood deliveries to mills increased by $22.40 \%$.

Table 2. Changes in wood deliveries and total costs of wood procurement regions $(\mathrm{A}-\mathrm{F})$ in scenario two, "energy reform".

\begin{tabular}{cccc}
\hline Delivery & Baseline Scenario & Scenario Two & Change-\% \\
\hline Log wood & 0.39 & 0.40 & 2.14 \\
Pulpwood & 0.58 & 0.58 & 1.22 \\
Energy wood & 0.02 & 0.04 & 118.84 \\
Chip wood & 0.01 & 0.02 & 22.40 \\
A & 0.13 & 0.14 & 2.47 \\
B & 0.14 & 0.14 & 0.57 \\
C & 0.33 & 0.32 & -3.22 \\
D & 0.16 & 0.16 & 3.15 \\
E & 0.11 & 0.15 & 29.54 \\
F & 0.12 & 0.13 & 7.06 \\
Delivering volume & 1.0 & 1.04 & 4.05 \\
Procurement costs & 1.0 & 1.16 & 15.95 \\
\hline
\end{tabular}

In the change by procurement region, the largest increase in delivery was in procurement region $\mathrm{E}(29.54 \%)$ and the decrease in procurement region $\mathrm{C}(3.22 \%)$. Wood deliveries were highest in the first half of the year. Especially in January, there were clearly more deliveries than in the other months. Roadside chipping applications are only made from January to May. The highest wood chipping volumes were in January.

\subsection{Scenario for Extensive Energy Reform}

In scenario three (extensive energy reform), total wood delivery volumes increased by $4.27 \%$ compared to the baseline scenario. The total wood-procurement costs increased by $16.07 \%$ (Table 3). In the change in wood assortments, the largest increase in the delivery volume was $125.10 \%$ for energy wood. The delivery volume of pulpwood changed the least, by $1.22 \%$. The volume of roadside chipping applications and deliveries increased by $29.99 \%$. 
Table 3. Changes in wood deliveries and total costs of wood procurement regions $(\mathrm{A}-\mathrm{F})$ in scenario three, "extensive energy reform".

\begin{tabular}{cccc}
\hline Delivery & Baseline Scenario & Scenario Three & Change-\% \\
\hline Log wood & 0.39 & 0.40 & 2.14 \\
Pulpwood & 0.58 & 0.58 & 1.22 \\
Energy wood & 0.02 & 0.04 & 125.10 \\
Chip wood & 0.01 & 0.02 & 29.99 \\
A & 0.13 & 0.15 & 2.78 \\
B & 0.14 & 0.14 & 1.39 \\
C & 0.33 & 0.32 & -3.03 \\
D & 0.16 & 0.16 & 3.15 \\
E & 0.11 & 0.15 & 29.54 \\
F & 0.12 & 0.13 & 7.06 \\
Delivering volume & 1.0 & 1.04 & 4.27 \\
Procurement costs & 1.0 & 1.16 & 16.07 \\
\hline
\end{tabular}

In the change by procurement region, the largest increase was in procurement region E (29.54\%) and the decrease in procurement region C (3.03\%). Deliveries were highest in the first half of the year. Especially in January, there were clearly more deliveries than in other months. Roadside chipping was done every month. The highest chipping volumes were in January.

\subsection{Sensitivity of Wood Procurement to Changes in Energy and Wood Production}

The optimization model allocated delivery volumes of wood assortments differently in the wood procurement regions (Figure 5). In scenario one, wood-procurement regions D and $\mathrm{F}$ were the only regions where delivery volumes increased as the others declined. These regions were also the least responsive to changes. In scenario two, procurement region $\mathrm{C}$ was the only region in which the delivery volume decreased as the others grew. The smallest change in the delivery volume occurred in region B. In scenario three, procurement region $C$ was the only region in which the delivery volume decreased as the others grew.

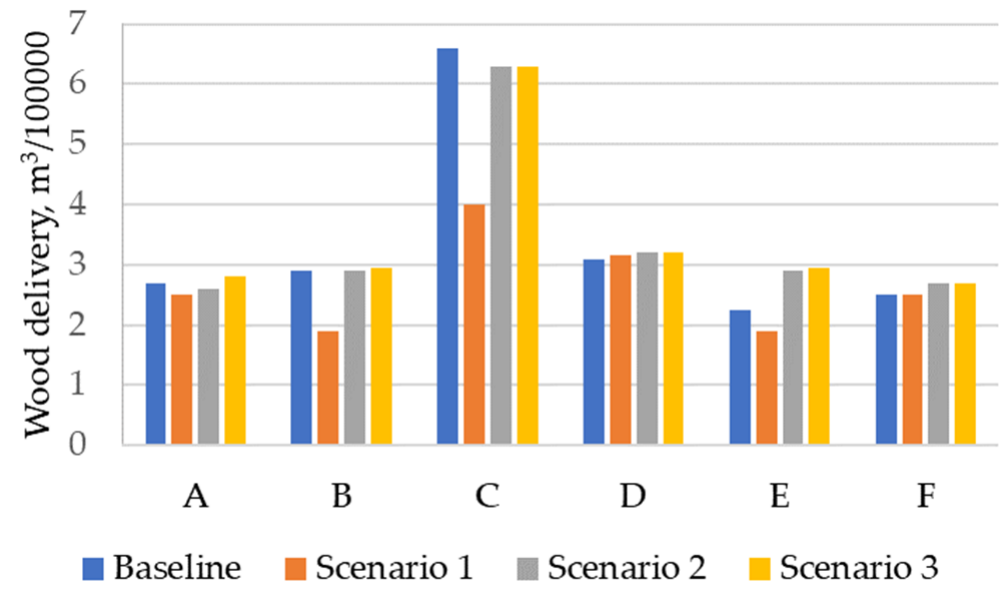

Figure 5. Comparison of changes in total wood-delivery volumes by wood-procurement regions (A-F).

At the wood-procurement region level, the greatest inter-regional sensitivity to changes in the production situation was in wood-procurement region three. Correspondingly, the smallest sensitivity was in wood-procurement region six (Table 4). Results were based on the average variations in the delivering volumes. 
Table 4. Average variation (standard deviation) in the deliveries of municipalities in woodprocurement regions $(\mathrm{A}-\mathrm{F})$ in the changes in the production situations, as well as the least (Min) and most (Max) responsive municipalities.

\begin{tabular}{cccc}
\hline Wood-Procurement Region & Average Variation & Min & Max \\
\hline A & 0.005 & Riihimaki & Janakkala \\
B & 0.023 & Hameenkoski & Hattula \\
C & 0.070 & Lempaala & Orivesi \\
D & 0.011 & Padasjoki & Kuhmoinen \\
E & 0.023 & Lahti & Iitti \\
F & 0.004 & Karkola & Artjarvi \\
\hline
\end{tabular}

At the municipal level, on average, the highest sensitivity of wood delivery to changes in the production situations was in Orivesi and the lowest in Karkola. According to the study, the seven most sensitive municipalities were Orivesi, Iitti, Ruovesi, Asikkala, Kuhmoinen, Hattula, and Lammi. Correspondingly, the following municipalities reacted the least to changes in the delivery demands of mills: Karkola, Lahti, Nastola, Riihimaki, Hameenkoski, Hollola, and Tuusula (Figure 6).

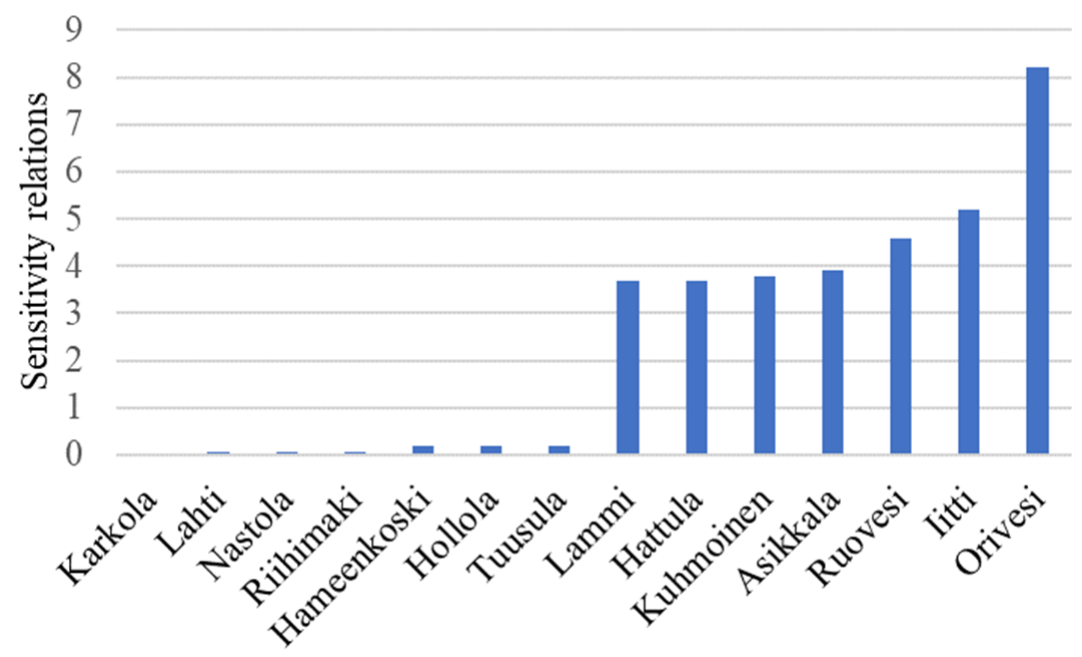

Figure 6. The least responsive municipalities and most sensitive municipalities to changes in wood demands of mills in the changes of production situation calculated based on standard deviations.

\section{Discussion}

The changes in wood procurement were optimized for four production situations of the forest industry: baseline and three future scenarios, and the effects of these changes on wood supply chains were considered from the perspective of integrated material and energy industries. The dynamic linear programming and optimization models were used in determining the capital-, cost-, and energy-efficient solutions to the scenarios, which were global optimal solutions of the Simplex algorithm [21,32]. Based on the results obtained, all the conditions set in the model could be met; in addition, all the supply chains related to wood procurement processes could be operated within the set limits. The literature provides important aspects of the forest industry with respect to industrial investments, wood markets, and European emission markets, which are included in the scenarios $[27,28,31]$. Therefore, an optimization model was formulated that was used to simultaneously solve these aspects as the optimal solution of the scenario. Pöyry (2009) reported aspects related to energy wood markets and European emission markets. Previous studies [21,30] modeled industrial investments, wood markets, and energy wood markets. In addition to these aspects, European emission markets will be very important aspects in future, which has been described using separate time-varying parameters. The same model structure has also been tested in previous studies in which its functionality and 
reliability were found to be adequate [21,30]; however, the price of European emission allowances were not formulated and used in previous models. In addition to increasing the energy efficiency at the strategic level, this model structure can be used for managing $\mathrm{CO}_{2}$ emissions of wood-procurement operations at tactical levels.

At the strategic level, emission cost parameters only had minor effects on allocations of wood supply chains, but, in future studies, supply chain energy efficiencies will be thoroughly analyzed because optimization will be executed at the tactical levels for an implementation of the selected strategy. For example, the effects and benefits of the price of emission allowance will be further analyzed for the varying percentage use of renewable biofuels by forest machines and trucks. In Finnish industries, the emission cost effect was minor because $100 \%$ renewable wood is procured from forests, which already provides carbon neutral wood flows into the industry $[15,33]$. In different industrial situations where operations occur under use of $100 \%$ renewables, the emission cost effect increases and, therefore, wood procurement is not very energy efficient, which may change strategic decisions towards carbon neutrality.

The study described the possible future situations of wood procurement of the industry using three scenarios: declining export, energy reform, and extensive energy reform, which were consistent formulations with the literature in Finland [31]. Based on the results, the assumed hypothesis set for the study was correct (Figure 3), which is discussed thoroughly in the following sections. In general, the objective function and its constraints of the optimization model provide sufficient tool and the results for strategic scenario analyses, as well as for reflection on their effects on integrated wood procurement of material and energy wood. However, the optimization model was not deliberately tuned to all local situations of the municipalities by fine-tuning the constraints and conditions. Therefore, the operative conditions of regional levels should be considered carefully when reviewing the results in practice. In this respect, additional research is also possible to execute local sensitivity analyses of the scenarios in the future. Previous studies of midstream supply chains have reported that it is difficult to generalize energy and cost benefits from a case study in industrial production symbiosis [26], but it is possible to show them upstream in wood supply chains, because investments are made annually instead of at a scale of decades.

The largest changes in the structure, volumes, and the overall total costs in wood procurement were hypothesized to be in the declining export scenario (scenario one), where domestic production in the pulp and paper industry decreased by $30 \%$ and production in the mechanical forest industry by $15 \%$. As expected, the changes of this first case were the most significant when it was compared to scenarios two and three. For example, the changes in the total wood delivery volumes could be considered significant, with the volume decreasing by almost $20 \%$ (Figure 3). If there were a sufficiently increased demand for energy wood by the energy industry, its share (wood chipping at mills) could be increased to compensate for declining material exports. Correspondingly, wood-harvesting and transportation machinery released from the operations should be utilized for the procurement of energy wood. Otherwise, this policy of industry is economically and socially unsustainable.

In the scenario of declining exports, the share of roadside chipping chains (roadside chipping and transport to the energy plants that use wood as chips) decreased slightly in terms of total wood supply (Table 1). In energy-wood logistics, the importance of good roadside inventories and large buffer terminals are emphasized, which increase the need for logistical planning. At the roadside, chipping operations were the most cost-effective from the point of view of large terminals and, on the other hand, it can then respond quickly to delivery changes. However, before chipping is possible in terminals, energy wood should be collected from roadside to these terminals, which is not capital-, cost-, and energy efficient at all if the dynamic optimization model is used in valuation of chains. Therefore, part of the roadside energy-wood chip stock will remain underutilized due to the increased chipping of energy-wood chips at mills (Figure 3), as well as the emphasis on demand at 
the beginning of 2017. The relative change in costs will be clearly larger than the change in volume, as the costs of energy-wood procurement are higher than those of the procurement costs of roundwood. In addition to higher wood-harvesting costs, energy wood inventories circulate more slowly than material wood inventories, which increase capital costs. Further, more machine resources are needed for energy-wood harvesting than in the equivalent amount of material-wood harvesting, as hourly productivity per machine unit decreases significantly with small-diameter trees $(\mathrm{cm})$ procured at energy-wood harvesting sites.

In the optimization of the scenario of declining exports, truck, forest machine, and chipper resources were reallocated geographically, i.e., the wood-procurement structure changed due to changes in the efficiencies between the wood-procurement regions (Figure 5). As the total procurement volume decreases, the local procurement volumes of municipalities must also be adjusted geographically, which, in the longer term, may mean the need to reduce several procurement managers. The greatest pressure for changes in procurement volumes is geographically in municipalities around the cities of Hameenlinna and Tampere (Table 4 and Figure 6). In the light of these results, the most important strategic change from the point of view of the management of the wood-procurement organization will be the structural change in procurement that reflect the reduced need for working capital that is related to the resources, which include managers, trucks, chipping machines, and forest machines.

In the energy reform scenario, the total consumption of forest energy is assumed to increase to the national target level of 13.5 million $\mathrm{m}^{3}$. Based on the results, the total costs of wood procurement will increase by 15.95\% (Table 2). This increase is largely explained by the increased supply of energy wood. The total amount of roundwood procurement as energy wood will increase by a few percent. The sharp increase in energy wood procurement will increase the capital costs because of the inventory growth and a slower turnover. The increase in forest energy supply is first reflected in work of energy wood purchase managers. The change may, in the long run, mean an increase in energy wood harvesting, chipper, and transportation machines. The roadside wood chippings are made in the first half of the year, i.e., during the coldest months. As a result, the chipper resource is at a low utilization rate during the summer, which can complicate the contract arrangement with entrepreneurs. This can have longer-term effects on profitability and resource availability. The greatest regional upward procurement pressure is on the Lahti environment (region E), where the increase in wood procurement is about 30\% when compared to the baseline scenario (Figure 5).

In the extensive energy reform scenario, the total use of forest energy is also expected to increase to 13.5 million $\mathrm{m}^{3}$, in addition, the biorefinery operations are expected to strengthen by using chipping of roundwood for energy. This is the most beneficial scenario towards carbon-neutral forest industry. The results show the wood demand for biorefineries as additional wood demand for existing energy plants. Based on the results, wood procurement volumes and costs follow the levels of the energy reform scenario (Table 3). The most significant difference in this future situation of the growth of biorefineries compared to the energy reform scenario is the increase in direct delivery volumes from roadside chipping, as well as the increase in other energy wood deliveries. Further, roadside chipping deliveries are made throughout the year, which is a better solution, but the emphasis is clearly on the first half of the year. Nevertheless, an increase of about one third compared to the baseline scenario in respect to the amount of direct roadside chipping delivery is likely to cause long-term needs to increase chipper resources, and possibly also an increase in forest machine and truck resources.

The sensitivity of operation efficiencies between municipalities and wood-procurement regions vary greatly in different production situations (Table 4 and Figure 6). From this, it can be concluded that the importance of strategical management of wood procurement is geographically crucial in the pursuit of operational efficiencies. Equally, the geographical location of new mills and the structure of wood procurement are both relevant factors when a country's industrial policy is directed towards low-carbon production. The sensitivity 
to change between regions shown in the results of the model is strongly explained by the municipal difference in available wood supply structure, as well as the transport distances to the places of use (Figure 2); however, a large increase in demand may increase wood procurement more than optimization can adjust it, e.g., demand may raise procurement costs relatively more than a feasible range will allow, especially if growth is sudden and strong [32]. This study did not consider the effects of the optimization method on timber trade in terms of wood supply and demand, which will be important research issues in the future. Based on the current situation, wood-procurement changes between municipalities and between procurement regions can be considered logical, based on the results obtained, as well as the constraints set for the model.

At the time of the study, extended energy reform was considered the plausible future scenario aiming toward carbon neutrality, but it was slightly too positive after considering the current pulp production investments [34]. It seems that the strategic solution of extensive energy reform provides a potential policy approach for carbon-neutral customeroriented supply chains in countries like Finland, but, before implementation, it needs tactical energy efficiency analysis in future studies in terms of sustainability, at least if the ultimate aim will be to implement a carbon-free forest industry and bioeconomy. In practice, focusing of procurement on a mill's energy wood assortments is really challenging, as forest resources of municipalities, as well as wood assortments ratios in stands, vary widely. Forest stands usually contain several timber species and potential wood assortments, making it impossible to allocate wood procurement to a single wood assortment. For example, the procurement of wood energy generally requires the purchase and harvesting of wood from an entire stand before actual energy wood harvesting. Small procurement organizations are constantly faced with this challenge, where success culminates very strongly in supply chain management. The optimization model used in the study was forced to use the restriction for purchase in an average forest stand (wood assortments) in a municipality, i.e., the purchase structure describes the prevailing supply as realistically as possible. This kind of supply and demand-based wood purchase and procurement, and its success can be considered a significant strategic competitive advantage for a procurement organization, especially in the face of strong production changes, such as those mentioned in this research.

\section{Conclusions}

The aim of the study was to optimize the wood procurement of integrated wood product and energy industries in changing production situations, and to consider the effects of these changes on practical wood procurement from the perspective of three strategic scenarios. The optimization model was adjusted to the scenarios by using dynamic constraints and by adding time-varying parameters of the price of European emission allowances for optimizing the effects of energy efficiency more effectively and accurately, which is the novel contribution to optimization results. In the declining export scenario, the negative changes in wood procurement were larger than the positive changes related to the increase in forest energy production and energy-wood demand. Thus, the research hypothesis was correct. The results also show that it is possible to change regions' wood procurement in a market-oriented manner, because the capital-, cost-, and energy efficiency of wood supply reveal a region's municipality-specific competitiveness. Therefore, the results obtained provide adequate accuracies for future wood-procurement management. However, additional research is needed to analyze the priorities of success factors toward carbon-free wood-procurement of the forest industry. Based on this study, the factors are functioning wood markets and sustainable wood-harvesting potential (purchase), inventory management, as well as the optimum utilization of machinery.

Author Contributions: T.P., writing — original draft; T.P. and J.T., writing-review and editing. Both authors have read and agreed to the published version of the manuscript.

Funding: This research received no external funding. 
Institutional Review Board Statement: Not applicable.

Informed Consent Statement: Not applicable.

Data Availability Statement: This study reported no data.

Conflicts of Interest: The authors declare no conflict of interest.

\section{Nomenclature}

$\mathrm{Z} \quad$ minimum procurement costs $(€)$,

$B_{i j t} \quad$ quantity of wood purchased $\left(\mathrm{m}^{3}\right)$ in municipality $j$ of wood assortment $i$ during period $t$,

$L_{i j t} \quad$ quantity of wood harvested $\left(\mathrm{m}^{3}\right)$ in municipality $j$ of wood assortment $i$ during period $t$,

$Y_{i j k t} \quad$ amount of wood transported $\left(\mathrm{m}^{3}\right)$ from municipality $j$ of wood assortment $i$ to mill $k$ during period $t$,

$Y H_{i j k t} \quad$ amount of wood chipped on the roadside $\left(\mathrm{m}^{3}\right)$ for wood assortment $i$ in municipality $j$ to mill $k$ during period $t$,

$M H_{i k t} \quad$ amount of wood chipped $\left(\mathrm{m}^{3}\right)$ for wood assortment $i$ at mill $k$ during period $t$,

$S_{i j t}$ amount of wood in the stand reserve $\left(\mathrm{m}^{3}\right)$ for wood assortment $i$ in municipality $j$ during period $t$,

$X_{i j t} \quad$ amount of wood by the roadside $\left(\mathrm{m}^{3}\right)$ for wood assortment $i$ in municipality $j$ during

period $t$

$M_{i k t} \quad$ amount of wood in inventory $\left(\mathrm{m}^{3}\right)$ for wood assortment $i$ at mill $k$ during period $t$,

$c b_{i j t} \quad$ purchase cost $\left(€ / \mathrm{m}^{3}\right)$ for wood assortment $i$ from municipality $j$ during period $t$,

$c l_{i j t} \quad$ harvesting costs $\left(€ / \mathrm{m}^{3}\right)$ for wood assortment $i$ from municipality $j$ during period $t$,

$c_{l a j t} \quad$ emission allowance price cost $\left(€ / \mathrm{m}^{3}\right)$ of fossil fuel for harvesting wood assortment $i$ from municipality $j$ during period $t$, transport costs $\left(€ / \mathrm{m}^{3}\right)$ for wood assortment $i$ from municipality $j$ to mill $k$ during $c y_{i j k t} \quad$ period $t$

cya $a_{i j k t} \quad$ emission allowance price cost $\left(€ / \mathrm{m}^{3}\right)$ for transportation wood assortment $i$ from municipality $j$ to mill $k$ during period $t$,

$c y h_{i j k t} \quad$ wood chipping and transport costs $\left(€ / \mathrm{m}^{3}\right)$ for wood assortment $i$ from municipality $j$ to mill $k$ during period $t$,

$c y h a_{i j k t} \quad$ emission allowance price cost $\left(€ / \mathrm{m}^{3}\right)$ for chipping and transportation wood assortment $i$ from municipality $j$ to mill $k$ during period $t$,

$c m h_{i k t} \quad$ wood chipping costs $\left(€ / \mathrm{m}^{3}\right)$ for wood assortment $i$ at mill $k$ during period $t$,

$c s_{i j t} \quad$ wood inventory costs $\left(€ / \mathrm{m}^{3}\right)$ for wood assortment $i$ at stand inventory in municipality $j$ during period $t$,

wood inventory costs $\left(€ / \mathrm{m}^{3}\right)$ for wood assortment $i$ at roadside in municipality $j$ during period $t$,

$c x_{i j t}$

$c m_{i k t}$

$\operatorname{Dmax}_{i k t}$ wood inventory costs $\left(€ / \mathrm{m}^{3}\right)$ for wood assortment $i$ at mill $k$ of period $t$,

$\operatorname{Dmin}_{i k t}$ maximum amount of wood required $\left(\mathrm{m}^{3}\right)$ for wood assortment $i$ at mill $k$ during period $t$, minimum amount of wood required $\left(\mathrm{m}^{3}\right)$ for wood assortment $i$ at mill $k$ during period $t$,

$\operatorname{Ymin}_{i j}$ maximum quantity $\left(\mathrm{m}^{3}\right)$ of wood transported by wood assortment $i$ from municipality $j$,

$\operatorname{Lmax}_{i j t}$ minimum quantity $\left(\mathrm{m}^{3}\right)$ of wood transported for wood assortment $i$ from municipality $j$, maximum amount of wood harvested $\left(\mathrm{m}^{3}\right)$ for wood assortment $i$ from municipality $j$

$\operatorname{Lmin}_{i j t}$ during $t$, minimum quantity of wood harvested $\left(\mathrm{m}^{3}\right)$ for wood assortment $i$ from municipality $j$ during period $t$,

$\operatorname{Smax}_{i j t}$ maximum quantity $\left(\mathrm{m}^{3}\right)$ of wood purchased for wood assortment $i$ from municipality $j$ during period $t$,

$\operatorname{Smin}_{i j t} \quad$ minimum quantity $\left(\mathrm{m}^{3}\right)$ of wood purchased for wood assortment $i$ from municipality $j$

$\operatorname{Mmax}_{i k t}$ maximum amount of wood in inventory $\left(\mathrm{m}^{3}\right)$ wood assortment $i$ at $\operatorname{mill} k$ during period $t$, $\operatorname{Mmin}_{i k t}$ minimum quantity of wood in inventory $\left(\mathrm{m}^{3}\right)$ for wood assortment $i$ at mill $k$ during period $t$,

$S I_{i j} \quad \begin{aligned} & \text { amount of wood in the stand reser } \\ & \text { beginning of the planning period, }\end{aligned}$ 


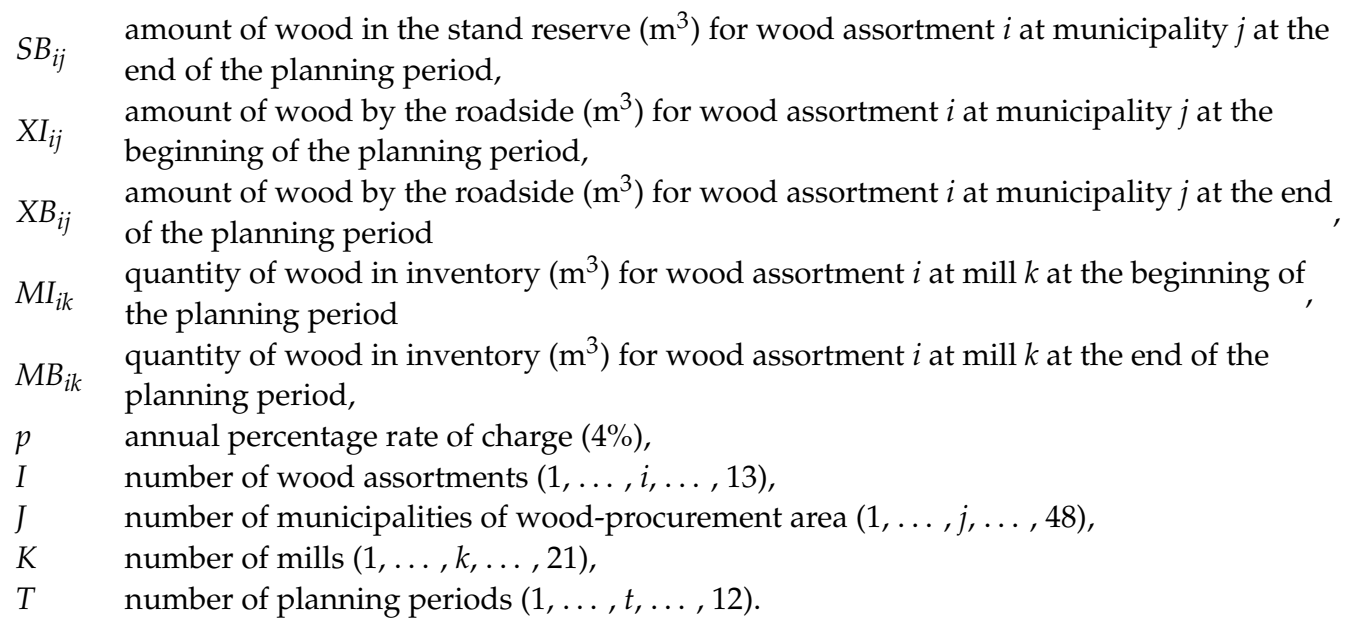

\section{References}

1. Hämäläinen, E.; Hilmola, O.-P. Energy efficiency at the paper mill—Dilemma of improvement. Energy Effic. 2017, 10, 809-821. [CrossRef]

2. HORIZON-CL5-2021-2022_version 2021-02-24. Cluster 5. Climate, Energy and Mobility. Working Document. Available online: https:/ / ec.europa.eu/info/horizon-europe/cluster-5-climate-energy-and-mobility_en (accessed on 12 April 2021).

3. Scarlat, N.; Dallemand, J.-F.; Monforti-Ferrario, F.; Nita, V. The role of biomass and bioenergy in a future bioeconomy: Policies and facts. Environ. Dev. 2015, 15, 3-34. [CrossRef]

4. EUR-Lex. A Roadmap for Moving to a Competitive Low Carbon Economy in 2050. Available online: https://eur-lex.europa.eu/ legal-content/EN/ALL/?uri=CELEX\%3A52011AE1389 (accessed on 12 April 2021).

5. Availability and Use of Solid Wood-Based Fuels in Finland in 2020. The Ministry of Economic Affairs and Employment, Helsinki, Finland. Available online: https://mmm.fi/en/en/forests/use-of-wood/wood-based-energy (accessed on 12 April 2021).

6. The Finnish Bioeconomy Strategy. Ministry of Agriculture and Forestry, Ministry of the Environment: Helsinki, Finland. 2014. Available online: https://biotalous.fi/wp-content/uploads/2014/08/The_Finnish_Bioeconomy_Strategy_110620141.pdf (accessed on 12 April 2021).

7. Hetemäki, L.; Nilsson, S. (Eds.) Conclusions and implications. In Information Technology and the Forest Sector, IUFRO World Series; IUFRO: Vienna, Austria, 2005; Volume 18, pp. 221-233.

8. Hilmola, O.-P.; Hämäläinen, E.; Hujala, M. Paper mill's distribution efficiency to emerging East European markets. Ind. Manag. Data Syst. 2014, 114, 1144-1168. [CrossRef]

9. National Forest Strategy 2025. Ministry of Agriculture and Forestry: Helsinki, Finland. 2015. Available online: https:// mmm.fi/documents/1410837/1504826/National+Forest+Strategy+2025/197e0aa4-2b6c-426c-b0d0-f8b0f277f332 (accessed on 12 April 2021).

10. Transport Emissions to Zero by 2045. Ministry of Transport and Communications: Helsinki, Finland. 2019. Available online: https:/ / valtioneuvosto.fi/en/article/-/asset_publisher/liikenteen-paastot-nollaan-vuoteen-2045-mennessa (accessed on 12 April 2021).

11. Government Report on the National Energy and Climate Strategy for 2030. Publications of the Ministry of Economic Affairs and Employment: Helsinki, Finland. 2017. Available online: http://julkaisut.valtioneuvosto.fi/bitstream/handle/10024/79247/ TEMjul_12_2017_verkkojulkaisu.pdf (accessed on 12 April 2021).

12. Annual Climate Report 2020. Publications of the Ministry of the Environment. Available online: http://urn.fi/URN:ISBN: 978-952-361-240-2 (accessed on 12 April 2021).

13. Thollander, P.; Ottosson, M. An energy efficient Swedish pulp and paper industry-exploring barriers to and driving forces for cost-effective energy efficiency investments. Energy Effic. 2008, 1, 21-34. [CrossRef]

14. Johansson, M.T.; Thollander, P. A review of barriers to and driving forces for improved energy efficiency in Swedish industryRecommendations for successful in-house energy management. Renew. Sustain. Energy Rev. 2018, 82, 618-628. [CrossRef]

15. Palander, T.; Haavikko, H.; Kärhä, K. Towards sustainable wood procurement in forest industry-The energy efficiency of larger and heavier vehicles in Finland. Renew. Sustain. Energy Rev. 2018, 96, 100-118. [CrossRef]

16. Palander, T. Tactical Models of Wood-Procurement Teams for Geographically Decentralized Group Decision Making. Ph.D. Thesis, University of Eastern Finland, Joensuu, Finland, 1998.

17. Palander, T.; Haavikko, H.; Kortelainen, E.; Kärhä, K. Comparison of Energy Efficiency Indicators of Road Transportation for Modeling Environmental Sustainability in "Green" Circular Industry. Sustainability 2020, 12, 2740. [CrossRef]

18. Hannus, J. Process Management; Logica: Helsinki, Finland, 2003.

19. Ericsson, K.; Nilsson, L.J.; Nilsson, M. New energy strategies in the Swedish pulp and paper industry. Energy Policy 2011, 39, 1439-1449. [CrossRef] 
20. Kong, L.; Price, L.; Hasanbeigi, A.; Liu, H.; Li, J. Potential for reducing paper mill energy use and carbon dioxide emissions through plant-wide energy audits: A case study in China. Appl. Energy 2013, 102, 1334-1342. [CrossRef]

21. Palander, T. Technical and economic analysis of electricity generation from forest, fossil, and wood waste fuels in a Finnish heating plant. Energy 2011, 36, 5579-5590. [CrossRef]

22. Palander, T.; Vainikka, M.; Yletyinen, A. Potential Mechanisms for Co-operation between Transportation Entrepreneurs and Customers: A Case Study of Regional Entrepreneurship in Finland. Croat. J. For. Eng. 2012, 33, 89-103.

23. Arivalagan, A.; Raghavendra, B.G.; Rao, A.R.K. Integrated energy optimization model for a cogeneration based energy supply system in the process industry. Electr. Power Energy Syst. 1995, 17, 227-233. [CrossRef]

24. Thollander, P.; Mardan, N.; Karlsson, M. Optimization as investment decision support tin a Swedish medium-sized iron foundry: A move beyond traditional energy auditing. Appl. Energy 2009, 86, 433-440. [CrossRef]

25. Nilsson, K. Cost-Effective Industrial Energy Systems-Multiperiod Optimizations of Operating Strategies and Structural Choices. Ph.D. Thesis, Division of Energy Systems. Linköping University, Linköping, Sweden, 1993.

26. Karlsson, M.; Wolf, A. Using an optimisation model to evaluate industrial symbiosis in the forest industry. J. Clean. Prod. 2008, 16, 1536-1544. [CrossRef]

27. Report on the Operation of the Finnish Wood Markets. The Ministry of Economic Affairs and Employment. 2009. Available online: https: / / www.researchgate.net/profile/Erkki-Verkasalo/publication/279183864_Comparison_of_alternative_roundwood_ pricing_systems_-_A_simulation_approach/links/5603c45108ae460e2704f60a/Comparison-of-alternative-roundwoodpricing-systems-A-simulation-approach.pdf (accessed on 12 April 2021).

28. Availability of Forest Bioenergy for Energy Production in Different Market Situations, Pöyry. 2009. Available online: https: / / docplayer.fi/6111313-Energiateollisuus-ry.html (accessed on 12 April 2021).

29. Daily EU ETS Carbon Market Price. 2021. Available online: https://ember-climate.org/data/carbon-price-viewer/ (accessed on 12 April 2021).

30. Palander, T. Modelling renewable supply chain for electricity generation with forest, fossil, and wood waste fuels. Energy 2011, 36, 5984-5993. [CrossRef]

31. Hetemäki, L.; Hänninen, R. Outlook for Finland's Forest Industry Production and Wood Consumption for 2015 and 2020. Work. Pap. Finn. For. Res. Inst. 2009, 122. Available online: https://www.researchgate.net/publication/285856898_Arvio_Suomen_ metsateollisuuden_tuotannosta_ja_puunkaytosta_vuosina_2015_ja_2020 (accessed on 12 April 2021).

32. Taha, H.A. Operations Research: An Introduction, 5th ed.; Prentice Hall: Hoboken, NJ, USA, 2011.

33. Palander, T.; Haavikko, H.; Kortelainen, E.; Kärhä, K.; Borz, S.A. Improving Environmental and Energy Efficiency in Wood Transportation for a Carbon-Neutral Forest Industry. Forests 2020, 11, 1194. [CrossRef]

34. Economic Survey. Investments of Forest Industry. Ministry of Finance. 2019. Available online: http://urn.fi/URN:ISBN: 978-952-367-023-5 (accessed on 12 April 2021). 